\title{
Reconstruction of millennial changes in dust emission, transport and regional sea ice coverage using the deep EPICA ice cores from the Atlantic and Indian Ocean sector of Antarctica
}

\author{
Hubertus Fischer ${ }^{\mathrm{a}, *}$, Felix Fundel ${ }^{\mathrm{a}}$, Urs Ruth ${ }^{\mathrm{a}}$, Birthe Twarloh ${ }^{\mathrm{a}}$, Anna Wegner ${ }^{\mathrm{a}}$, \\ Roberto Udisti ${ }^{\mathrm{b}}$, Silvia Becagli ${ }^{\mathrm{b}}$, Emiliano Castellano ${ }^{\mathrm{b}}$, Andrea Morganti ${ }^{\mathrm{b}}$, \\ Mirko Severi ${ }^{b}$, Eric Wolff ${ }^{\mathrm{c}}$, Genevieve Littot ${ }^{\mathrm{c}}$, Regine Röthlisberger ${ }^{\mathrm{c}}$, \\ Rob Mulvaney ${ }^{c}$, Manuel A. Hutterli ${ }^{\mathrm{d}, \mathrm{c}}$, Patrik Kaufmann ${ }^{\mathrm{d}}$, \\ Urs Federer $^{\mathrm{d}}$, Fabrice Lambert ${ }^{\mathrm{d}}$, Matthias Bigler ${ }^{\mathrm{d}, \mathrm{g}}$, \\ Margareta Hansson e, Ulf Jonsell e, Martine de Angelis ' , \\ Claude Boutron ${ }^{f}$, Marie-Louise Siggaard-Andersen ${ }^{\mathrm{g}}$, \\ Jorgen Peder Steffensen ${ }^{\mathrm{g}}$, Carlo Barbante ${ }^{\mathrm{h}, \mathrm{i}}$, \\ Vania Gaspari ${ }^{\mathrm{h}}$, Paolo Gabrielli ${ }^{\mathrm{i}}$, Dietmar Wagenbach ${ }^{\mathrm{j}}$ \\ a Alfred-Wegener-Institute for Polar and Marine Research, Columbusstrasse, D-27568 Bremerhaven, Germany \\ ${ }^{\mathrm{b}}$ Department of Chemistry, University of Florence, Via della Lastruccia 3, 50019 Sesto Fiorentino (Florence), Italy \\ ${ }^{\mathrm{c}}$ British Antarctic Survey, High Cross, Madingley Road, Cambridge CB3 OET, UK \\ ${ }^{\mathrm{d}}$ Climate and Environmental Physics, Physics Institute, University of Bern, Sidlerstr.5, 3012 Bern, Switzerland \\ ${ }^{e}$ Department of Physical Geography and Quaternary Geology Stockholm University, 10691 Stockholm, Sweden \\ ${ }^{\mathrm{f}}$ Laboratoire de Glaciologie et Géophysique de l'Environnement (LGGE), CNRS-UJF, BP96 38402 Saint-Martin-d'Hères Cedex, France \\ ${ }^{\mathrm{g}}$ Niels Bohr Institute, University of Copenhagen, Juliane Maries Vej 30, 2100 Copenhagen OE, Denmark \\ ${ }^{\mathrm{h}}$ Department of Environmental Sciences, University Ca' Foscari of Venice, Dorsoduro 2137, 30123 Venice, Italy \\ ${ }^{\mathrm{i}}$ Institute for the Dynamics of Environmental Processes-CNR, Dorsoduro 2137, 30123 Venice, Italy \\ ${ }^{j}$ Institute for Environmental Physics, University of Heidelberg, INF229, 69120 Heidelberg, Germany
}

Received 12 March 2007; received in revised form 31 May 2007; accepted 1 June 2007

Available online 12 June 2007

Editor: M.L. Delaney

\begin{abstract}
Continuous sea salt and mineral dust aerosol records have been studied on the two EPICA (European Project for Ice Coring in Antarctica) deep ice cores. The joint use of these records from opposite sides of the East Antarctic plateau allows for an estimate of changes in dust transport and emission intensity as well as for the identification of regional differences in the sea salt aerosol source. The mineral dust flux records at both sites show a strong coherency over the last 150 kyr related to dust emission changes in the glacial Patagonian dust source with three times higher dust fluxes in the Atlantic compared to the Indian Ocean sector of the Southern Ocean (SO). Using a simple conceptual transport model this indicates that transport can explain only $40 \%$ of the atmospheric dust concentration changes in Antarctica, while factor 5-10 changes occurred. Accordingly, the main cause for the
\end{abstract}

\footnotetext{
* Corresponding author.

E-mail address: hubertus.fischer@awi.de (H. Fischer).
} 
strong glacial dust flux changes in Antarctica must lie in environmental changes in Patagonia. Dust emissions, hence environmental conditions in Patagonia, were very similar during the last two glacials and interglacials, respectively, despite $2-4{ }^{\circ} \mathrm{C}$ warmer temperatures recorded in Antarctica during the penultimate interglacial than today. 2-3 times higher sea salt fluxes found in both ice cores in the glacial compared to the Holocene are difficult to reconcile with a largely unchanged transport intensity and the distant open ocean source. The substantial glacial enhancements in sea salt aerosol fluxes can be readily explained assuming sea ice formation as the main sea salt aerosol source with a significantly larger expansion of (summer) sea ice in the Weddell Sea than in the Indian Ocean sector. During the penultimate interglacial, our sea salt records point to a $50 \%$ reduction of winter sea ice coverage compared to the Holocene both in the Indian and Atlantic Ocean sector of the SO. However, from 20 to 80 ka before present sea salt fluxes show only very subdued millennial changes despite pronounced temperature fluctuations, likely due to the large distance of the sea ice salt source to our drill sites.

(C) 2007 Elsevier B.V. All rights reserved.

Keywords: paleoclimate; ice core; Antarctica; sea salt; mineral dust

\section{Introduction}

Antarctic glacial/interglacial temperature changes have been reconstructed over up to eight glacial cycles using deep ice cores drilled on the Antarctic plateau (Petit et al., 1999; Watanabe et al., 2003; EPICA community members, 2004; Brook et al., 2005; EPICA community members, 2006; Jouzel et al., in press) and on coastal ice domes (Steig et al., 1998; Morgan et al., 2002). Such climate records are generally interpreted as being representative for the whole SO region, which plays a key role in glacial/interglacial climate changes (Blunier et al., 1997; Knorr and Lohmann, 2003; Stocker and Johnsen, 2003) and the global carbon cycle (Archer et al., 2001; Köhler et al., 2005; Toggweiler et al., 2006). However, while the large-scale glacial/interglacial

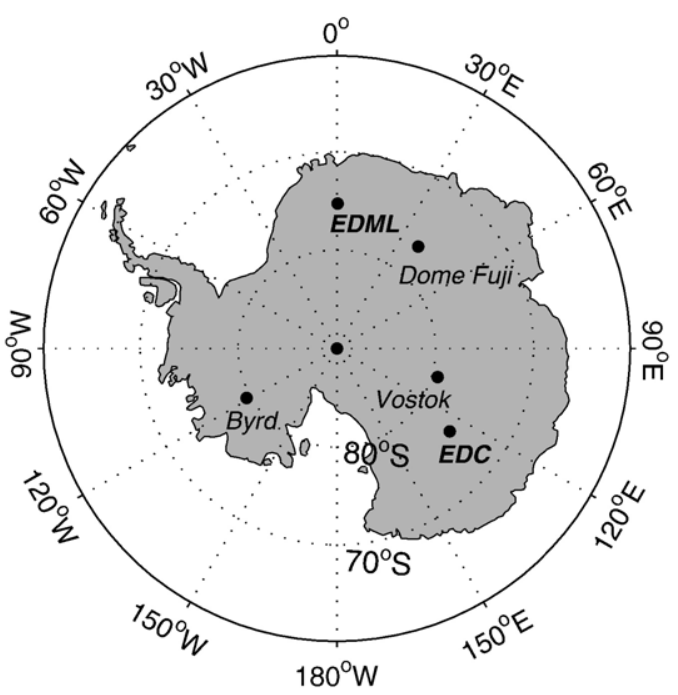

Fig. 1. Map of the Antarctic continent indicating the EPICA drill sites in Dronning Maud Land (EDML) facing the Atlantic sector of the SO and at Dome C (EDC) facing the Indian Ocean sector of the SO together with previously drilled deep ice cores on the Antarctic plateau. changes are imprinted in all those records (Watanabe et al., 2003) the influence of different air mass origin allows us to reconstruct also regional differences in climate evolution (Morgan et al., 2002). Moreover, while temperature changes have been documented in many Antarctic ice cores, regional information on accompanying environmental changes is still limited. Especially, temporally resolved information on a dust induced iron fertilization of marine phytoplankton productivity (Martin, 1990) and on reduced gas exchange and decreased mixing of the ocean due to an increase in sea ice cover (Toggweiler, 1999; Stephens and Keeling, 2000; Köhler et al., 2005) is needed to constrain the carbon cycle/ climate feedback. Independent information on mineral dust deposition and sea ice coverage in different regions of Antarctica can be deduced from aerosol records in deep Antarctic ice cores (Petit et al., 1990; Delmonte et al., 2002; Röthlisberger et al., 2002; Wolff et al., 2003; Udisti et al., 2004; Wolff et al., 2006; Fischer et al., 2007).

Within the European Project for Ice Coring in Antarctica (EPICA) two deep ice cores have recently been drilled (Fig. 1). The core at Dome C (EPICA community members, 2004) (EDC: $75^{\circ} 06^{\prime} \mathrm{S}, 123^{\circ} 21^{\prime} \mathrm{E}$, $3233 \mathrm{~m}$ above sea level) in the Indian Ocean sector of Antarctica comprises undisturbed ice core records over the last approximately $800 \mathrm{kyr}$ (Jouzel et al., in press). The second ice core was drilled at Kohnen station in Dronning Maud Land (EPICA community members, 2006) (EDML: $75^{\circ} 00^{\prime} \mathrm{S}, 00^{\circ} 04^{\prime} \mathrm{E}, 2882 \mathrm{~m}$ above sea level). With a snow accumulation rate 2-3 times higher than at EDC it provides higher resolution records down to Marine Isotope Stage (MIS) 4. Moreover, due to its location it represents the first ice core closely linked to climate changes in the Atlantic sector of the SO.

In the following, we report on mineral dust (represented by non-sea salt calcium $\left(\mathrm{nssCa}^{2+}\right)$ ) and sea salt aerosol (represented by sea salt sodium $\left(\mathrm{ssNa}^{+}\right)$) records derived from both ice cores in decadal to centennial 
resolution. The change of these parameters in the EDC ice core has been previously discussed for the last $45 \mathrm{kyr}$ in high resolution (Röthlisberger et al., 2002) and in millennial resolution over the last $740 \mathrm{kyr}$ (Wolff et al., 2006). Here we extend the discussion of the centennial sea salt and mineral dust record from EDC to the last 150 kyr. More importantly, we contrast the EDC data to the first continuous aerosol records from the Atlantic sector of the Antarctic ice sheet as archived in the deep EDML ice core. This way we can make use of the coherencies and differences between the two records located on opposite sides of the East Antarctic plateau allowing for an estimate of changes in transport intensity and for the identification of regional differences in aerosol source strengths.

\section{Methods}

\subsection{Age scales}

The age scale (called EDC3) for the EDC core was derived using an accumulation and ice flow model constrained by independent age markers (Parrenin et al., 2007). For internal coherence, a dependent EDML age scale (called EDML1) has been derived for the last $150 \mathrm{kyr}$ by synchronizing the EDC and EDML ice core (Ruth et al., 2007; Severi et al., 2007) using volcanic horizons in sulfate, in the dielectric profile as well as electrolytic conductivity down to a depth of $2366 \mathrm{~m}$ (equivalent to $128 \mathrm{ka}$ before present (BP) where present is defined as 1950). Below this depth no unambiguous volcanic synchronization could be established and we relied on a few pronounced dust match points to synchronize both cores. Due to the hemispheric and often global impact of volcanic eruptions on sulfuric acid deposition and due to the common glacial dust source for EDML and EDC in Patagonia (Grousset et al., 1992; Basile et al., 1997; Delmonte et al., 2004a,b) this procedure provides unambiguous isochrones in both ice cores and allows for direct comparison of regional differences in the two cores independent of absolute dating uncertainties. Below $150 \mathrm{ka}$ BP no unambiguous matching has been accomplished yet (Ruth et al., 2007). Accordingly, we will restrict the discussion of the EDML chemistry data to the last 150 kyr.

For this time period the absolute dating uncertainty of the EDC3 age scale is always better than $6000 \mathrm{yr}$ (Parrenin et al., 2007). During MIS 3 the absolute uncertainty of the age scale is less than 1500 yr. More important for our comparison of the EDC and EDML ice cores is the internal consistency of the EDC3 and the EDML1 age scale, which is defined by the synchronization uncertainty. The maximum synchronization uncertainty at $130 \mathrm{ka} \mathrm{BP}$ is $450 \mathrm{yr}$ and even larger for older ages. However, during most of the record the maximum synchronization uncertainty is smaller and on average about $40 \mathrm{yr}$ (Ruth et al., 2007). Note, that this maximum synchronization uncertainty is a conservative estimate and the typical synchronization uncertainty is even smaller (on average $6 \mathrm{yr}$ over the last $130 \mathrm{kyr}$ ). Thus, the interpolation error is always small compared to the absolute dating uncertainty and allows for unprecedented synchronization of these two independent climate archives. Among others, this becomes crucial when directly comparing aerosol fluxes at both sites at a given point in time.

\subsection{Chemical analyses}

Samples for chemical analyses have been taken using a continuous flow melting device, which precludes contact of the melt water with contaminated ice core surfaces (Röthlisberger et al., 2000). EDML Concentrations of $\mathrm{Ca}^{2+}$ and $\mathrm{Na}^{+}$presented here have been determined using ion chromatography (IC), while the top $580 \mathrm{~m}$ of $\mathrm{Ca}^{2+}$ data at Dome $\mathrm{C}$ have been determined using continuous flow analysis (CFA) (Röthlisberger et al., 2002; Wolff et al., 2006). Analytical details for the EDC chemistry data set are summarized in Wolff et al. (2006). The uncertainty in IC analyses is mainly determined by the lab dependent blank contribution, while the instrument detection limit is one order of magnitude lower. The average blank contribution for EDML lies between 3 and $50 \%$ of the $\mathrm{Ca}^{2+}$ concentration for average glacial and interglacial conditions, respectively, and between 2 and $5 \%$ in the case of $\mathrm{Na}^{+}$. The reproducibility of the $\mathrm{Ca}^{2+}$ and $\mathrm{Na}^{+}$data is typically better than $10 \%$ and even better than $5 \%$ during glacial conditions. During interglacial periods the reproducibility of $\mathrm{Ca}^{2+}$ concentrations lower than $2 \mathrm{ppb}$ deteriorates to around $50 \%$. The CFA based EDC Holocene record is not affected by this blank contribution. For the EDML ice core the top $113 \mathrm{~m}$ were not sampled. The depth interval $113-450 \mathrm{~m}$ in the EDML ice core covering the time period from 1200 to 6700 a BP has been sampled in $5 \mathrm{~cm}$ resolution and then averaged to $1 \mathrm{~m}$ intervals for this study. Analyses of these 6400 high-resolution samples were done in 4 continuous batches in 4 different laboratories. Due to different lab procedures blank values and reproducibility of the different batches vary from lab to lab. To account for the interlaboratory differences in mean blank contribution and to gain a homogeneous record throughout the Holocene, the concentration values have been corrected by subtracting the mean concentration difference in neighboring $5 \mathrm{~m}$ depth intervals in each of the adjacent 
batches with the depth interval $273-450 \mathrm{~m}$ taken as reference interval. To avoid a bias by high concentration peaks we used the median to estimate the mean concentration level. In doing so, all data are corrected to the same average blank contribution, assuming that no change in average atmospheric concentrations occurred in the adjacent $5 \mathrm{~m}$ intervals used for the correction, representing a time interval of approximately $150 \mathrm{yr}$. With this procedure we are able to avoid interlaboratory offsets between the batches while retaining as much longterm variability in the individual batches as possible. For the sodium record the average correction was $-0.8 \mathrm{ppb}$ (the maximum correction was $-2.4 \mathrm{ppb}$ applied to one batch) which is less than $5 \%$ (maximum 14\%) of the average concentration. For the calcium record the correction was on average $0.2 \mathrm{ppb}$ (maximum correction $-3.0 \mathrm{ppb}$ applied to one batch), i.e. about $9 \%$ (maximum $130 \%$ ) of the average concentration. Note, that these interlaboratory corrections affect only the Holocene record and are rather small for $\mathrm{Na}^{+}$. For Holocene samples with low $\mathrm{Ca}^{2+}$ concentrations these corrections are significant and we have to state that we cannot determine the lower envelope of Holocene $\mathrm{Ca}^{2+}$ concentrations with certainty using IC. Note however, that these corrections do not affect any of our conclusions on glacial aerosol variability, where $\mathrm{Ca}^{2+}$ concentrations are more than one order of magnitude higher. The depth interval $450-2774 \mathrm{~m}$ has been analyzed entirely in one lab in $1 \mathrm{~m}$ resolution and no interlaboratory offsets had to be corrected.

The contributions of sea salt and mineral dust to the total $\mathrm{Ca}^{2+}$ and $\mathrm{Na}^{+}$content have been corrected using the sea salt $\mathrm{Ca}^{2+} / \mathrm{Na}^{+}$and the average crustal $\mathrm{Ca}^{2+} / \mathrm{Na}^{+}$ratio of $R_{\mathrm{m}}=0.038$ and $R_{\mathrm{t}}=1.78$ (Bowen, 1979) (in bulk weight units), respectively (Röthlisberger et al., 2002). While this correction is of minor importance for interglacial sea salt aerosol (on average 10\%) it becomes important for mineral dust in the Holocene where approximately $24 \%$ of the total $\mathrm{Ca}^{2+}$ content in the EDML core is derived from sea salt aerosol. In the peak glacial (20$30 \mathrm{ka} \mathrm{BP}$ ) this effect is reversed. Here $\mathrm{nssCa}^{2+}$ is on average only $5 \%$ lower than total $\mathrm{Ca}^{2+}$ while about $28 \%$ of the total sodium is of crustal origin. The composition of crustal tracers as recorded in ionic ice core data may differ from $R_{\mathrm{t}}$ which is based on the bulk elemental composition of insoluble crustal material. Note, that $R_{\mathrm{t}}$ may vary dependent on the composition of crustal material as well as on size dependent fractionation processes of different minerals during the formation of mineral dust aerosol. Ice core observations at EDC point to an $R_{\mathrm{t}}$ which may be

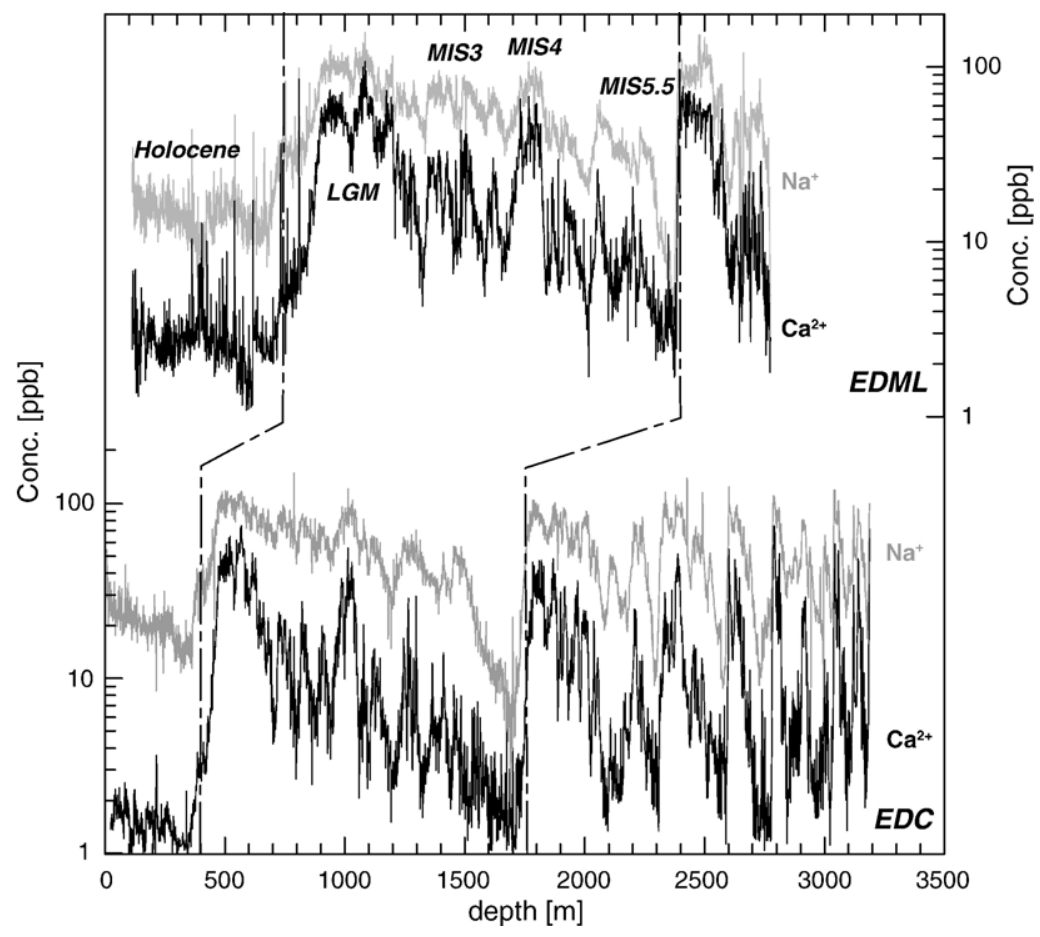

Fig. 2. $\mathrm{Na}^{+}$(grey line) and $\mathrm{Ca}^{2+}$ (black line) concentration records (logarithmic scale) as measured on the EDML (top) and EDC ice cores (bottom) on their individual depth scale in $1 \mathrm{~m}$ resolution. The dashed-dotted lines indicate pronounced isochronous dust changes during the last two glacial/ interglacial transitions in both records. 


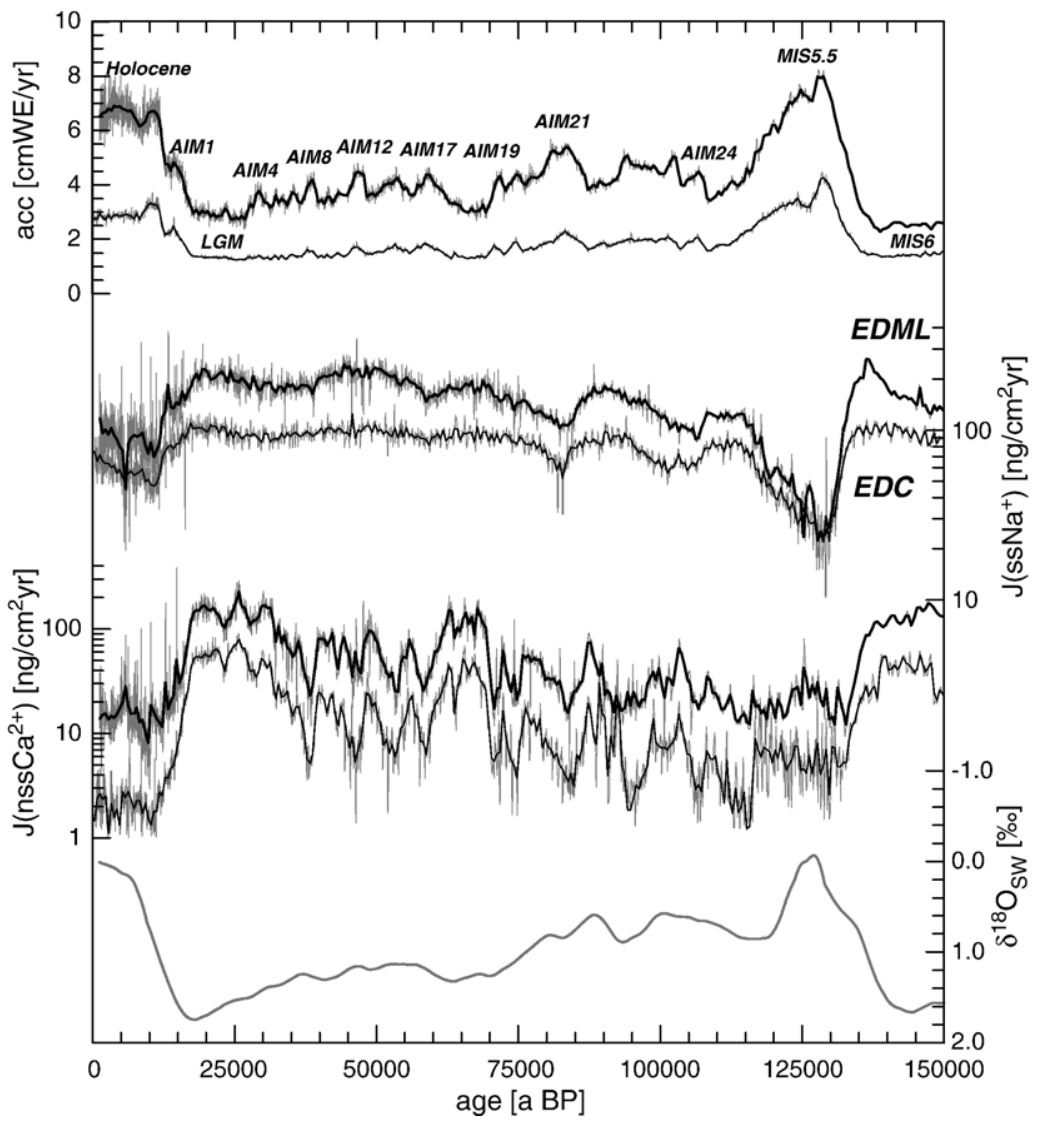

Fig. 3. Sea salt $\mathrm{Na}^{+}\left(\mathrm{ssNa}^{+}\right)$and non-sea salt $\mathrm{Ca}^{2+}\left(\mathrm{nssCa}^{2+}\right)$ flux records (logarithmic scale) over the last $150 \mathrm{kyr}$ at EDML and EDC on the common EDML1/EDC3 age scale (Parrenin et al., 2007; Ruth et al., 2007). For comparison past accumulation rates at the site of deposition are given as derived from isotope temperature changes $\left(\delta^{18} \mathrm{O}, \delta \mathrm{D}\right)$ at EDML and EDC (EPICA community members, 2004, 2006) which have been used for flux calculations. Data are shown in $1 \mathrm{~m}$ resolution (thin grey lines) and $500 \mathrm{yr}$ averages (thick black line for EDML and thin black line for EDC), the latter accounting for the loss in temporal resolution down core. Also depicted are reconstructed changes in benthic $\delta^{18} \mathrm{O}$ representative of long-term sea level changes on the new EDML1/EDC age scale (Bintanja et al., 2005).

closer to 1 (Bigler et al., 2006). While the effect of such a variability in $R_{\mathrm{t}}$ changes the nssCa ${ }^{2+}$ estimate only by a few percent, its effect on $\mathrm{ssNa}^{+}$is considerable. For instance reducing $R_{\mathrm{t}}$ within reasonable bounds to 1 (Bigler et al., 2006) or increasing it to 3.5 changes the $\mathrm{ssNa}^{+}$estimate by $10-30 \%$ for glacial conditions in Antarctica (Fischer et al., 2007). Note, that $R_{\mathrm{t}}$ may also change from glacials to interglacials due to potentially shifting sources and weathering conditions, however, within reasonable limits of $R_{\mathrm{t}}$ this effect is too small to significantly affect our conclusions.

\subsection{Accumulation rates and deposition fluxes}

The total average deposition flux $J_{\text {tot }}$ at an ice core site (Fischer et al., 2007) can be approximated by

$J_{\text {tot }}=C_{\text {ice }} A=v_{\text {dry }} C_{\text {air }}+W / \rho_{\text {air }} C_{\text {air }} A$.
The first term on the right hand side of this equation parameterizes the dry deposition and the second term the wet deposition flux with $v_{\text {dry }}$ the total mean dry deposition velocity, $W$ the scavenging ratio, $\rho_{\text {air }}$ the density of air, $C_{\text {air }}$ the atmospheric aerosol concentration and $A$ the average accumulation rate. In low accumulation areas dry deposition dominates and the total flux is essentially independent of changes in accumulation and almost proportional to the atmospheric aerosol concentrations. Accordingly, we will discuss aerosol flux records in this study, which are more representative of atmospheric aerosol concentrations. Knowledge of the latter is a prerequisite for quantitative estimates of source strength or transport changes in the past. The total deposition flux was calculated by multiplying the measured ice concentration $C_{\text {ice }}$ with reconstructed accumulation rates (Figs. 2 and 3). Both at EDC and EDML the accumulation rate is estimated from the 
stable water isotope $\left(\delta^{18} \mathrm{O}, \delta \mathrm{D}\right)$ profiles (after correction for changes in the isotopic composition of sea water due to continental ice mass changes) essentially assuming thermodynamic control of the water vapor saturation pressure (EPICA community members, 2006; Parrenin et al., 2007). Second order corrections of non-thermodynamic effects on the accumulation rate at EDML have been made using the spatial variability in accumulation rates upstream of the drill site (EPICA community members, 2006) derived from firn cores and an extended surface radar survey (Oerter et al., 2000; Steinhage et al., 2001; Graf et al., 2002; Rybak et al., 2005) and at EDC by a one-dimensional flow model (Parrenin et al., 2007). The error of the reconstructed accumulation rates is estimated to be $30 \%$ for glacial times and significantly less for warm periods, where the precipitation regime is similar to today. This is also supported by comparing these continuous thermodynamically derived accumulation rates at EDML with discrete accumulation rates derived from the unstrained layer thickness between volcanic match points (Severi et al., 2007). Both accumulation estimates agree typically within $\pm 20 \%$. Because the accumulation information based on $\delta^{18} \mathrm{O}$ can be calculated continuously in high resolution over the entire length of the core, we will use the thermodynamically derived accumulation rate in the following to derive aerosol fluxes. Based on the errors in accumulation rates and ion concentrations, the aerosol fluxes are constrained to better than $30 \%$ for the large majority of the samples and to better than $60 \%$ for very low Holocene $\mathrm{Ca}^{2+}$ concentrations. Note, that although these errors are considerable they are small compared to the order of magnitude change in glacial/interglacial $\mathrm{Ca}^{2+}$ concentrations and cannot explain systematic glacial variations on millennial time scales in concentration and flux records.

\subsection{Upstream correction}

In contrast to the EDC ice core, which is located on a dome position, the EDML ice core lies at a saddle position of the ice divide with small (about $1 \mathrm{~m} / \mathrm{yr}$ ) horizontal flow velocities. Accordingly, while the ice at Dome $\mathrm{C}$ originates at the current drill site, deeper ice at EDML originates from upstream positions at higher altitudes, where temperatures and accumulation rates are lower and the atmospheric aerosol concentrations may be slightly different. E.g. ice with an age of $150 \mathrm{ka} \mathrm{BP}$ has been deposited $160 \mathrm{~km}$ upstream (EPICA community members, 2006; Huybrechts et al., 2007). Note, that geographic effects in aerosol concentrations are small compared to the glacial/interglacial changes (Sommer et al., 2000; Göktas et al., 2002). As outlined above the true total aerosol flux at the site of deposition should be almost independent from the local snow accumulation rate in low accumulation areas where dry deposition prevails. Accordingly, we used the local accumulation rate at the site of initial deposition to calculate total aerosol fluxes.

\section{Results}

The $\mathrm{Ca}^{2+}$ and $\mathrm{Na}^{+}$concentration records for both ice cores are shown on a depth scale in Fig. 2. The EDC record provides unprecedented data over 8 full glacial cycles, while the EDML record shows only 2 unambiguous glacial maxima. In return, the EDML record exhibits higher annual layer thicknesses down to a depth of $1900 \mathrm{~m}$, allowing for higher resolution records down to an age of approximately $80 \mathrm{ka} \mathrm{BP}$. The concentration records show comparable glacial/interglacial variations both at EDML and EDC with 1-2 orders of magnitude higher sea salt and mineral dust concentrations during glacial periods and significant millennial dust variability during marine isotope stage 2-4. Similar glacial/ interglacial variability has been also reported from Vostok (de Angelis et al., 1997) and Taylor Dome (Mayewski et al., 1996) as far as temporal resolution allowed.

One major achievement for the EPICA ice cores is the unambiguous stratigraphic link between the two EPICA ice cores (Ruth et al., 2007; Severi et al., 2007). This common EDML1/EDC3 age scale allows for direct comparison of aerosol flux records and their interpretation in terms of atmospheric aerosol concentrations. In Fig. 3 the $\mathrm{ssNa}^{+}$and $\mathrm{nsSCa}^{2+}$ flux records are plotted. The accompanying changes in the snow accumulation rate are given for comparison. Clearly, both records show a very high covariance between both sites in each of the aerosol species. However, $\mathrm{nssCa}^{2+}$ fluxes at EDML are about 3 times higher than at EDC showing that atmospheric $\mathrm{nssCa}^{2+}$ concentrations are substantially higher at EDML than at $\mathrm{EDC}$. Isotopic fingerprinting for Dome $\mathrm{C}$ samples showed that Patagonia is the dominant source of mineral dust deposited at that site in the glacial (Basile et al., 1997; Delmonte et al., 2007) as also supported by dust modeling (Lunt and Valdes, 2001; Mahowald et al., 2006). In the interglacial an additional Australian dust source may be possible at Dome C (Revel-Rolland et al., 2006; Delmonte et al., 2007). Isotopic fingerprinting of mineral dust has not been accomplished yet at EDML, but a strong influence of Australian dust sources to EDML appears to be very unlikely, given its geographic location which is much closer to South America and downwind of the 
cyclonically curved atmospheric pathway from Patagonia (Reijmer et al., 2002). Accordingly, we attribute the higher atmospheric nssCa ${ }^{2+}$ concentrations at EDML to the greater proximity of EDML to the Patagonian dust source.

Also sea salt fluxes are about a factor of 2 higher at EDML than at EDC indicating higher atmospheric sea salt aerosol concentrations in Dronning Maud Land. Note, that in the case of sea salt wet deposition may have a stronger influence than is the case for dust. Transport of sea salt aerosol is closely linked to cyclonic activity and a higher contribution by wet deposition of sea salt aerosol may be expected. This holds especially at EDML, where large parts of the recent annual accumulation is derived from a few single snow fall events per year (Reijmer and van den Broeke, 2001), while at EDC only non-frontal diamond dust is observed. Model studies show that circum-Antarctic cyclone activity in the glacial was most likely reduced (Krinner and Genthon, 1998) due to the extended sea ice cover and an accompanying northward shift of the atmospheric polar front, reducing the effect of single precipitation events on sea salt transport to EDML at that time. Given the high covariance between both records and the extremely low glacial accumulation of 1-3 cm WE/yr at both sites a dominant influence of wet deposition during cold climate periods appears to be unlikely. This implies that glacial sea salt fluxes are largely representative of the true variations in atmospheric concentrations.

Most striking are the substantial changes in dust and sea salt fluxes over the last glacial cycle similarly found at both sites. The nssCa ${ }^{2+}$ flux decreased by a factor of about 10 during the last two glacial/interglacial transitions (Fig. 3) at both sites. At the same time the ssNa ${ }^{+}$ flux decreased at EDC by a factor of 2 and at EDML by a factor of 3 from the Last Glacial Maximum (LGM) to the Holocene and by a factor of 4-8 during the penultimate transition, essentially due to much lower $\mathrm{ssNa}^{+}$fluxes during the interglacial MIS 5.5. Apart from the glacial/ interglacial changes in dust emissions, strong millennial variations in the $\mathrm{nssCa}^{2+}$ flux are also observed, while such variations are very subdued in the sea salt record.

\section{Discussion}

\subsection{Mineral dust}

A key question is, how much of the glacial/interglacial and millennial variations in the glacial is due to changes in the aerosol transport or changes in aerosol source strength. Using the coherent change in glacial dust fluxes at both EPICA sites from opposite sides of the East Antarctic plateau $\left(r^{2}=0.82\right.$ for $100 \mathrm{yr}$ averages), we are now able to constrain the influence of transport changes on the changes in mineral dust flux in Antarctica. Assuming the atmospheric aerosol concentration close to the source is given by $C_{\text {air }}(0)$ and an air parcel is transported away from the source, the atmospheric aerosol concentration $C_{\text {air }}$ at any time $t$ along the transport trajectory can to first order be approximated by

$C_{\text {air }}(t)=C_{\text {air }}(0) \exp (-t / \tau)$ or

$\log \left[C_{\text {air }}(t) / C_{\text {air }}(0)\right]=-t / \tau$

where $t$ is the transport time and the average atmospheric residence time $\tau$ along the transport route is controlled by wet and dry deposition (Hansson, 1994). $\tau$ is typically on the order of a few days to weeks (Mahowald et al., 1999; Gong et al., 2002; Reijmer et al., 2002; Werner et al., 2002). If two sites with transport times $t_{1}$ and $t_{2}$ (e.g. EDML and EDC) are considered, the logarithmic air concentration at site 2 can be expressed by the concentration at site 1 according to

$\log \left[C_{\text {air }}\left(t_{2}\right)\right]=\log \left[C_{\text {air }}\left(t_{1}\right)\right]-\Delta t / \tau$

where $\Delta t=t_{2}-t_{1}$ is the transport time difference along the two trajectories and where we assume that the atmospheric residence time along both transport routes is comparable.

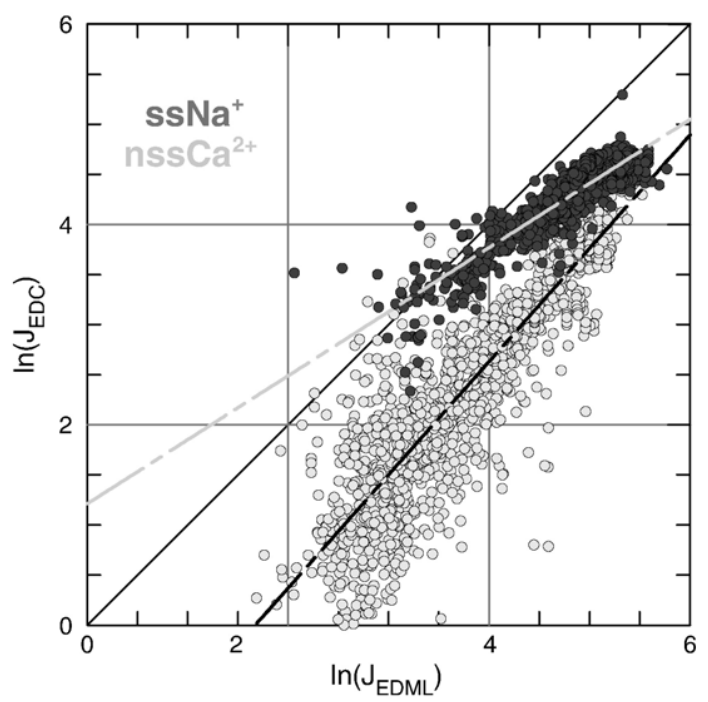

Fig. 4. Scatter plot of logarithmic $\mathrm{nssCa}^{2+}$ (light grey dots) and $\mathrm{ssNa}^{+}$ (dark grey dots) fluxes in the EDC vs. EDML ice cores in $100 \mathrm{yr}$ resolution according to Eq. (1). If transport remains unchanged the difference of the data points from the first bisecting line should stay constant. For visual guidance a linear regression through all data points has been added which shows a slope close to 1 for nss $\mathrm{Ca}^{2+}$ (dark grey line) and around 0.6 for $\mathrm{ssNa}^{+}$(light grey line). 
Accordingly, if the aerosol is derived from the same source at both sites (as is the case for glacial Patagonian dust in Antarctica) the difference in the logarithmic atmospheric aerosol concentration (thus, the deposition flux in Antarctic low accumulation areas), should be $\Delta t / \tau$. The offset $\Delta t / \tau$ may change for different climate conditions. For example if transport velocities intensify as hypothesized for colder climate conditions (Petit et al., 1999), $\Delta t$ and, thus, the logarithmic offset should become smaller. If the atmospheric residence time $\tau$ is considerably lengthened as hypothesized for cold periods (Yung et al., 1996; Petit et al., 1999) the offset should also be reduced.

As shown in Fig. 4 the difference of logarithmic $\mathrm{nssCa}^{2+}$ fluxes in the ice (representative of atmospheric $\mathrm{nssCa}^{2+}$ concentrations) at EDC and EDML stayed rather constant, providing observational evidence that transport parameters for dust transport from Patagonia to Antarctica have not changed strongly over the last glacial cycles. Alternatively, both $\Delta t$ and $\tau$ may have changed in the same way compensating each other's transport effect. However, it seems unlikely that this was the case during all time periods over the last $150 \mathrm{kyr}$. In any case the change in atmospheric concentration at the drill site is only dependent on the joint effect of transport time and residence time which, based on our results, was limited. In Table 1 the average differences (representative of $\Delta t / \tau$ ) of logarithmic fluxes between EDML and EDC are summarized for individual time periods. Based on our conceptual model it becomes clear that $\Delta t / \tau$ is between 1 and 2 for all time periods over the last glacial cycle, implying that the difference in transport time is similar to the atmospheric residence time and is on the order of a week approximately in line with back trajectory studies (Reijmer et al., 2002). For the glacial intervals, where Patagonian dust is dominant (Grousset et al., 1992; Basile et al., 1997; Delmonte et al., 2004a), the offset lies between 1 and 1.5 with the lower values for peak glacial conditions (LGM, MIS6). This points to a somewhat faster transport or a larger residence time during the coldest periods but the decrease in $\Delta t / \tau$ from MIS3 to the LGM is still within the uncertainty in Table 1. Taking the values in Table 1 at face value a LGM decrease in $\Delta t / \tau$ compared to MIS3 could explain increases in the atmospheric $\mathrm{nssCa}^{2+}$ concentration of approximately $40 \%$ assuming that this change were entirely due to changes in atmospheric residence time and if we assume both an average atmospheric residence time and a transport time to EDML of approximately a week during MIS 3 (Gong et al., 2002). Only if we use an unrealistically long transport time, which is 6 times larger than the atmospheric residence time, can we explain the observed factor of 5 changes in the glacial $\mathrm{nssCa}^{2+}$ flux records with our simple conceptual transport model. The largest difference in Table 1 is found between the Holocene and the LGM. Taken at face value this would point to a slower transport or a reduced atmospheric residence time during the Holocene, which could explain a glacial increase by $70 \%$. However, the Holocene $\mathrm{Ca}^{2+}$ flux at EDML has to be regarded as an upper limit due to the relatively high blank contribution in this time interval and accordingly the real difference in $\Delta t / \tau$ in Table 1 is significantly smaller. E.g. reducing the average Holocene concentration at EDML for a blank contribution of only $1 \mathrm{ppb}$ would reduce $\Delta t / \tau$ to 1.5 , i.e. a value similar to MIS3 and 4.

Interestingly, the scatter of the nssCa ${ }^{2+}$ flux data in Fig. 4 decreases with increasing flux values, i.e. for colder climate conditions. This can only partly be explained by the larger measurement uncertainty for low $\mathrm{Ca}^{2+}$ concentrations during warm periods. Accordingly, this suggests a higher transport variability or a variable input of Australian dust export to Antarctica for warm climate conditions. In summary, we conclude that both transport intensity as well as variability changed over time but played only a secondary role for the observed dust changes in line with atmospheric circulation models (Krinner and Genthon, 1998; Reader and McFarlane, 2003; Mahowald et al., 2006). Thus, the observed changes in $\mathrm{nssCa}^{2+}$ fluxes predominantly reflect changes in source strength.

For glacial dust this implies strongly increased dust emissions in Patagonia, which are most pronounced during the LGM. The penultimate glacial but also the cold interval between 60-70 ka BP show extraordinarily high $\mathrm{nssCa}^{2+}$ fluxes comparable to the environmental

Table 1

Average \pm standard deviation of the difference in logarithmic $\mathrm{nssCa}^{2+}$ fluxes in $100 \mathrm{yr}$ resolution at EDML and EDC representing the average ratio of the transport time difference between the two sites and the atmospheric residence time as controlled by wet and dry deposition en route

\begin{tabular}{|c|c|c|c|c|c|c|}
\hline \multirow{2}{*}{$\begin{array}{l}\text { Time } \\
\text { period }\end{array}$} & Holocene & LGM & MIS3 & MIS4-5.4 & MIS5.5 & MIS6 \\
\hline & $1-10 \mathrm{ka}$ BP & $20-30 \mathrm{ka} \mathrm{BP}$ & $30-60 \mathrm{ka} \mathrm{BP}$ & $60-120 \mathrm{ka} \mathrm{BP}$ & $120-130 \mathrm{ka} \mathrm{BP}$ & $130-150 \mathrm{ka} \mathrm{BP}$ \\
\hline$\Delta t / \tau$ & $(2.01 \pm 0.47)$ & $0.96 \pm 0.17$ & $1.41 \pm 0.40$ & $1.56 \pm 0.84$ & $(1.45 \pm 0.51)$ & $1.16 \pm 0.39$ \\
\hline
\end{tabular}

The Holocene value represents an upper limit due to the larger blank contribution to ion chromatographically determined $\mathrm{Ca}^{2+}$ concentrations at EDML compared to the CFA data used at EDC. During MIS5.5 both EDML and EDC are affected by the blank level. 
conditions during the LGM. Parallel to the $\mathrm{nssCa}^{2+}$ flux maxima in Antarctica, terrigenous records in marine sediments in the northern Scotia Sea also point to higher mineral dust input from southern Patagonian sources (Diekmann et al., 2000), however this study did not distinguish between aeolian and lateral transport of suspended particles to the sediment. The rest of the last glacial is characterized by intermediate $\mathrm{nssCa}^{2+}$ fluxes, hence mineral dust emissions in Patagonia, which are strongly but not linearly related to temperature changes recorded in Antarctica (Fig. 5) (Wolff et al., 2006). Especially, each of the Antarctic Isotope Maxima (AIM) (EPICA community members, 2006) indicated in Fig. 3 is accompanied by a significant decline in $\mathrm{nssCa}^{2+}$ fluxes at EDML and EDC. This points to synchronous changes (reduced aridity and/or lower wind speeds) in the Patagonian source regions during AIMs. Of special importance in Fig. 3 are also the apparently comparable environmental conditions during the last two interglacials. This points to similar precipitation rates and wind speeds in Patagonia while temperatures in Antarctica were $2-4{ }^{\circ} \mathrm{C}$ higher in MIS5.5 than in the Holocene (EPICA community members, 2006).

Little is known about the long-term change in local Patagonian climate beyond the LGM. For the LGM, terrestrial records ((Markgraf et al., 1992) and references therein) and climate models (Wainer et al., 2005) suggest increased aridity leeside of the Andes and a northward expansion and potential strengthening of the westerlies (Moreno et al., 1999). The latter is connected to the northward expansion of sea ice found in marine sediment records (Gersonde et al., 2005) and in line with our sea salt reconstructions discussed in Section 4.2. Model simulations on the change in the southern hemisphere westerlies are inconsistent (Shin et al., 2003; Butzin et al., 2005; Otto-Bliesner et al., 2006). While an idealized atmospheric model without continents shows a clear glacial northward shift of peak westerly winds (Williams and Bryan, 2006), one model study with a complex coupled ocean/atmosphere climate model (Shin et al., 2003) shows even a slight southward shift of the peak wind stress in the SO. Interestingly, a northward expansion of the westerlies is also observed for recent winter conditions compared to summer in NCEP/NCAR reanalysis data (Kalnay et al., 1996), while the core of the westerlies in the SO does not shift in latitude.

Another possible factor acting on dust emission may be the reduction of sea level exposing substantial shelf areas especially on the Atlantic side off Patagonia. Comparison of the $\mathrm{EDC} \mathrm{nssCa}^{2+}$ record with coast line reconstructions for the Argentinian shelf (Wolff et al., 2006) showed that the major glacial/interglacial $\mathrm{nssCa}^{2+}$ decrease occurred prior to any significant sea level rise. In addition the millennial climate variability during MIS 3 is also accompanied by significant $\mathrm{nssCa}^{2+}$ flux variations (Fig. 3), but has not been accompanied by sea level changes at similar high frequencies. In contrast to the delayed global sea level rise relative to the mineral dust decrease, an early glacier retreat before $17 \mathrm{ka}$ BP has been reported from Tierra del Fuego and other mid-
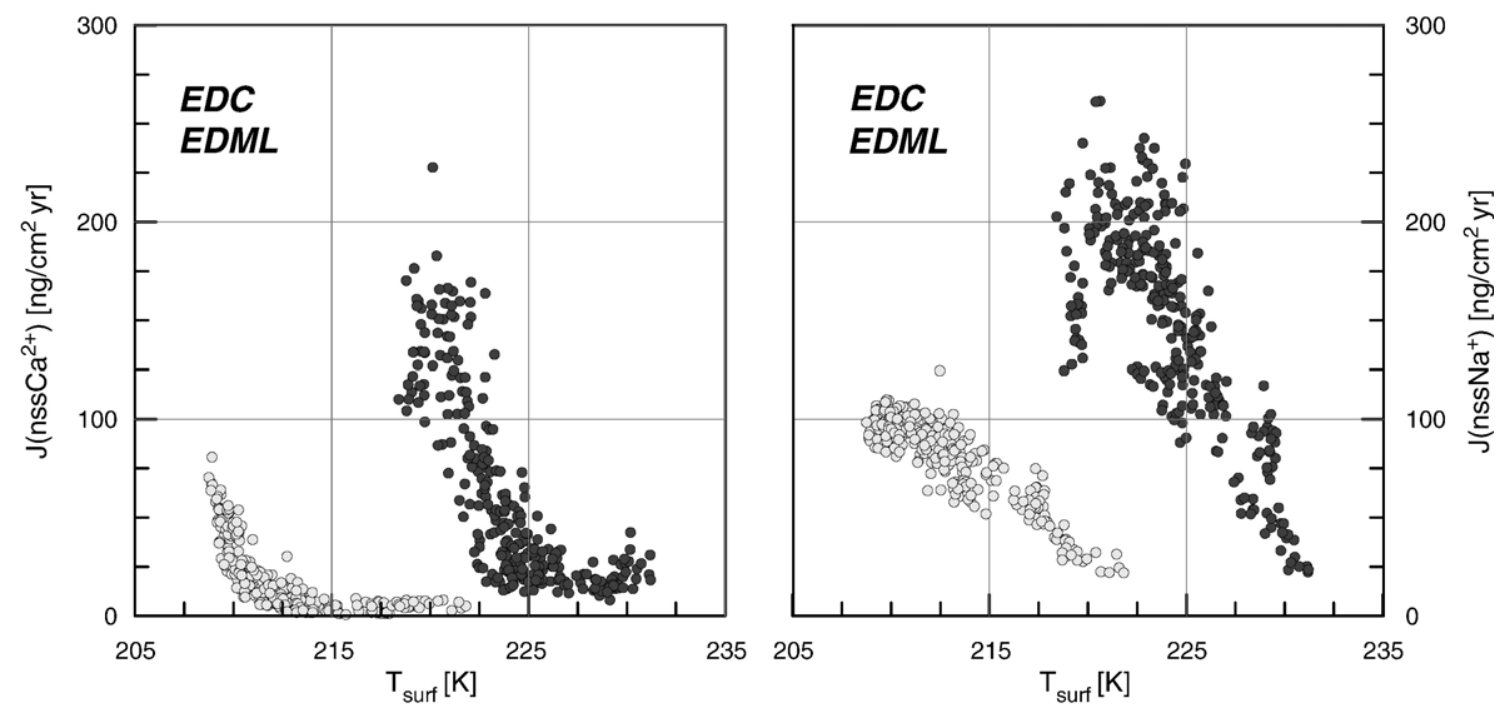

Fig. 5. Temperature dependence of nssCa ${ }^{2+}$ (left) and $\mathrm{ssNa}^{+}$(right) fluxes in $500 \mathrm{yr}$ resolution at EDML (dark grey dots) and EDC (light grey dots). Surface temperatures have been derived from $\delta^{18} \mathrm{O}(\mathrm{EDML})$ and $\delta \mathrm{D}(\mathrm{EDC})$ using the spatial isotope/temperature gradient in the respective region (EPICA community members, 2004, 2006). 
latitude glaciers (Sugden et al., 2005; Schaefer et al., 2006), supporting a close connection of glaciation and continental dust sources in southern South America. Outwash of mineral dust material has been strongly enhanced during glacial expansion of southern Andean ice masses, providing a potential active source for mineral dust mobilization in the glacial. In summary we suggest that a combination of changes in glacial outwash, aridity and wind speed are mainly responsible for the glacial/interglacial mineral dust changes recorded in Antarctica (Mahowald et al., 2006) while the influence of sea level changes is small for the rapid decrease in dust fluxes at the beginning of the termination and during MIS 3.

\subsection{Sea salt}

A quantification of transport changes for sea salt aerosol is even more difficult as in the case of dust. Sea salt concentration increases more strongly at EDML than at EDC for colder climate conditions leading to an increase in the difference of logarithmic sea salt concentration in Fig. 4. However, this cannot be used to quantify transport changes as in the case of glacial dust because the sea salt source regions for the Atlantic and Indian Ocean sector of Antarctica are not the same and sea salt source strength as well as transport may have changed independently in both regions. In view of the largely expanded sea ice coverage around Antarctica a longer transport time from the open ocean to the Antarctic plateau is expected in glacial periods and any intensification of transport from the open ocean would have to overcompensate that effect. An increased inflow of marine air masses from the open ocean leading to an increased sea salt aerosol flux seems also in contradiction with the strongly depleted stable water isotope $\left(\delta^{18} \mathrm{O}, \delta \mathrm{D}\right)$ levels (EPICA community members, 2004, 2006) and reduced snow accumulation rates at both sites, pointing to a stronger depletion of marine air masses in water vapor and most likely also sea salt aerosol during transport.

Also an explanation of the site dependent glacial increase in sea salt fluxes in terms of sea salt source strength is not straightforward. The canonical interpretation of changes in sea salt aerosol is an increased sea/air particle flux at the open ocean surface due to increased wind speeds. This, however, is in contradiction to the greatly increased sea ice cover (Gersonde et al., 2005) during glacial periods. Aerosol formation from brine water, as for example experienced during the formation of frost flowers in sea ice leads and polynyas, has recently been identified as an additional effective source for sea salt aerosol (further on referred to as "sea ice salt"). Precipitation of mirabilite $\left(\mathrm{Na}_{2} \mathrm{SO}_{4} \cdot 10 \mathrm{H}_{2} \mathrm{O}\right)$ from sea water during brine formation leads to a characteristic sulfate depletion compared to the average sea water composition. This fractionation has been regularly observed in atmospheric sea salt aerosol concentrations at coastal Antarctic sites in winter (Wagenbach et al., 1998; Rankin et al., 2000) showing the importance of the brine water source for the local sea salt aerosol budget. Brine and frost flower formation was also suggested as a possible mechanism for the glacial/interglacial increase in sea salt concentrations in ice cores on the high Antarctic plateau (Wolff et al., 2003, 2006). Only recently, year-round aerosol sampling on the East Antarctic plateau revealed evidence of sulfate depleted sea salt aerosol during austral winter (Hara et al., 2004), which we interpret as significant influence of sea ice formation on the sea salt aerosol budget also for the interior of Antarctica (Wolff et al., 2006; Fischer et al., 2007). In the following we will explore whether we can explain the observed changes in sea salt fluxes, if we take sea ice salt formation into account, while recognizing that there remains some controversy about this interpretation as long as we have no quantitative source estimate for sea ice salt production.

Due to wind driven opening of leads this sea ice salt aerosol formation process occurs throughout the sea ice cover and continuously in coastal polynyas. Based on diatom evidence in $\mathrm{SO}$ sediment records it was shown that the circum-Antarctic winter sea ice cover during the LGM was enhanced by approximately a factor of two from 19 to $39 \cdot 10^{6} \mathrm{~km}^{2}$ (Gersonde et al., 2005). Although the reconstruction of the summer sea ice edge is hampered by the lack of siliceous sediments in regions of second year sea ice, some evidence for substantial summer sea ice exists for the LGM in the Atlantic and Indian Ocean sector of the SO (Gersonde et al., 2005). This indicates that the glacial summer sea ice was as large as recent winter sea ice coverage in the Atlantic sector while it was not extended in the Indian Ocean sector of the SO. Sea surface temperatures in summer sea ice regions (e.g. in coastal polynyas in the Weddell Sea) have been well below the freezing point during the LGM (Gersonde et al., 2005), allowing for considerable sea ice formation also during summer. This summer sea ice salt formation would add to the sea ice salt aerosol emission in winter and further enhance the annually averaged aerosol source strength of this process. If we take at first order the sea ice salt contribution to the Antarctic sea salt budget to be proportional to the total sea ice cover in winter and summer we expect a factor of 2 increase in the Indian ocean and a factor up to 3 
increase in the Atlantic sector of the SO, favorably in line with our observations in the EDC and EDML ice cores.

Concentrating on the variability in sea salt flux in parallel to millennial climate variations during MIS 3 (Fig. 4) it becomes clear that a warming during AIMs does not lead to a clear response in sea salt fluxes. This casts doubt on a quantitative use of sea salt in ice cores as sea ice proxy. During peak glacial times the potential sea ice salt formation zone extends as far north as $50^{\circ} \mathrm{S}$. Sea ice salt produced in areas at the outer edge of the sea ice cover has to travel a very long distance before it reaches an ice core site on the Antarctic plateau. Due to this long transport time it experiences substantial depletion by wet and dry deposition en route. Accordingly, we suggest that the farther north the sea ice salt formation zone extends during cold periods the less efficient is this edge area to add to the sea salt aerosol budget at Antarctic ice core drill sites. Looking at the sea salt variations in MIS 3 in more detail (Fig. 6) we see that at EDC no imprint on sea salt fluxes can be found during AIMs whatsoever while the record at EDML suggests a tendency to rapidly reduced sea salt fluxes at the onset of most of the warming events and a gradual recovery thereafter. Although this effect is rather weak it may point to a decline in the summer sea ice extent in the Weddell Sea sector which may react more sensitively to the warming events during MIS 3.

A major difference in $\mathrm{ssNa}^{+}$fluxes exists for the penultimate warm period. During MIS 5.5 the sea salt flux in the EDML ice core was reduced by a factor of 4 while it was lowered by a factor of 2-3 at EDC compared to Holocene conditions in line with significantly warmer temperatures at EDC and EDML (EPICA

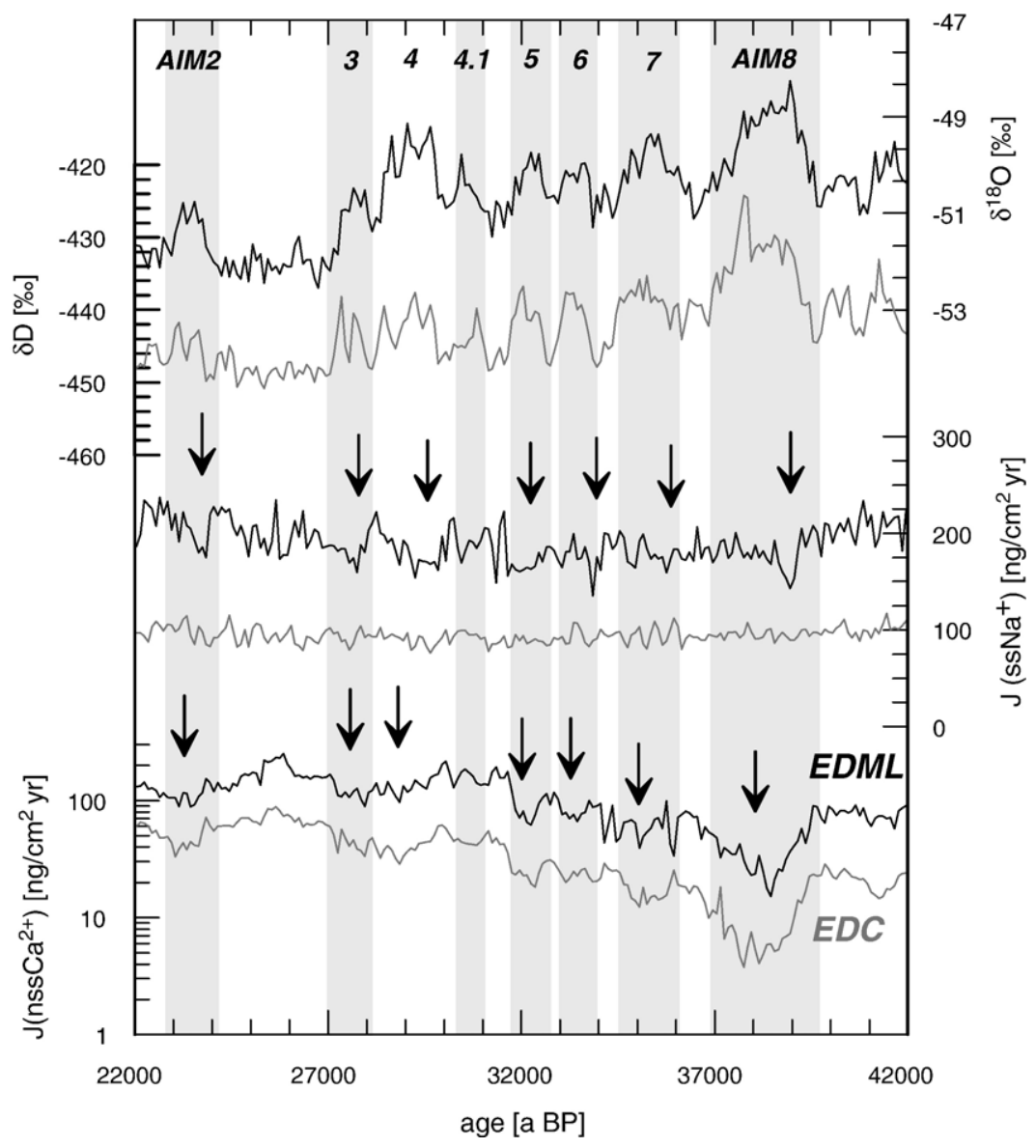

Fig. 6. High-resolution (100 yr averages) plots of stable water isotopes, $\mathrm{ssNa}^{+}$fluxes and $\mathrm{nsSCa}^{2+}$ fluxes in the EDML (black line) and EDC (grey line) ice cores during the time interval 22-42 ka BP on the common EDML1/EDC3 age scale (Parrenin et al., 2007; Ruth et al., 2007). Isotope temperatures show Antarctic Isotope Maxima (AIM) during this period (EPICA community members, 2006) which are also reflected in lowered $\mathrm{nssCa}^{2+}$ fluxes at both sites (indicated by arrows in the bottom panel, note the logarithmic y-scale). Sea salt aerosol at EDML tends to a rapid decline at the onset of most of the AIMs (indicated by arrows in the middle panel) while no significant changes in sea salt aerosol can be observed at EDC. 
community members, 2006). Because summer sea ice is nearly absent in the Indian Ocean sector for Holocene conditions, this implies that only a reduction in the winter sea ice salt source could explain the sea salt decrease in this region during the warmer MIS 5.5. In the Atlantic sector of the SO an even stronger decline in sea ice coverage during MIS 5.5 is indicated by our $\mathrm{ssNa}^{+}$data, possibly related to a reduction of both winter and summer sea ice in the Weddell Sea. This is also supported by changes in marine sediments, indicating a southward shift of the opal deposition belt by $3-5^{\circ}$ latitude (Bianchi and Gersonde, 2002) at that time.

\section{Conclusions}

Sea salt and mineral dust aerosol records are representative for basin-wide atmospheric catchment areas of aerosol transported onto the East Antarctic ice sheet. The records allow us to draw a clearer picture on the timing of environmental changes in Patagonia and the SO and their influence on aerosol formation in parallel to climate variations in Antarctica over the last $150 \mathrm{kyr}$.

Sea salt records at both sites allow for the first time a basin-wide estimate of sea salt aerosol emissions, which support an accompanying change in sea ice cover over the complete time interval from the penultimate glacial to the present. The coherence of the two sea salt records from opposite sides of the Antarctic ice sheet indicates a waxing and waning of sea ice, which was generally synchronous in the Atlantic and the Indian Ocean sector of the SO on glacial/interglacial time scales. The sensitivity of sea salt fluxes to temperature changes (Fig. 5), however, is higher in the Weddell Sea sector, a fact which we attribute to a more vigorous change in sea ice cover and the additional role of summer sea ice extent on sea ice salt formation in this area. We note, that for very cold climate conditions sea salt changes become increasingly insensitive to temperature changes probably related to the long transport distance of aerosol formed at the northern margin of the sea ice cover. Accordingly, the use of sea salt as quantitative proxy for sea ice coverage is hampered and requires a rigorous calibration against marine sediment data for different time slices, experimental studies of the modern sea ice salt source as well as refined model studies about its change in the past.

Using our dust records from sites facing different sectors of the SO with greatly different distances to Patagonia and using a simple conceptual transport model we can rule out a substantial variation in transport as being the main factor being responsible for the observed $\mathrm{nssCa}^{2+}$ changes during glacial times as also supported by atmospheric circulation models (Krinner and Gen- thon, 1998; Reader and McFarlane, 2003). Instead our results point to temporal changes in the strength of the Patagonian mineral dust source in parallel to temperature variations in Antarctica. The three times higher $\mathrm{nsSCa}^{2+}$ fluxes at EDML also point to a threefold higher aeolian dust input into the Weddell Sea sector of the SO, potentially related to a stronger dust fertilization in this region. This effect may be amplified by a potential dust storage effect of the greatly extended winter and summer sea ice coverage as indicated in our $\mathrm{ssNa}^{+}$record. The extension of summer and winter sea ice in this region is also expected to have a strong effect on bottom water formation, gas exchange and wind shear of the surface ocean likely related to a reduced ventilation of the deep SO with strong impacts on the global carbon cycle (Köhler et al., 2005). Accordingly, our data will allow for a better time resolved, basin-wide quantification of potential dust fertilization on marine export productivity and investigation of the effect of the sea ice extent on gas exchange and water mass formation.

\section{Acknowledgments}

This work is a contribution to the European Project for Ice Coring in Antarctica (EPICA), a joint European Science Foundation/European Commission scientific programme, funded by the EU (EPICA-MIS) and by the national contributions from Belgium, Denmark, France, Germany, Italy, the Netherlands, Norway, Sweden, Switzerland and the United Kingdom. The main logistic support was provided by IPEV and PNRA (at Dome C) and AWI (at Dronning Maud Land). We thank the logistics and drilling teams and all helpers in the field for making the science possible. This is EPICA publication no. 170.

\section{Appendix A. Supplementary data}

Supplementary data associated with this article can be found, in the online version, at doi:10.1016/j. eps1.2007.06.014.

\section{References}

Archer, D., Winguth, A., Lea, D., Mahowald, N., 2001. What caused the glacial/interglacial atmospheric $\mathrm{pCO}_{2}$ cycles? Rev. Geophys. 38, 159-189.

Basile, I., Grousset, F.E., Revel, M., Petit, J.R., Biscaye, P.E., Barkov, N.I., 1997. Patagonian origin of glacial dust deposited in East Antarctica (Vostok and Dome C) during glacial stages 2, 4 and 6. Earth Planet. Sci. Lett. 146, 573-589.

Bianchi, C., Gersonde, R., 2002. The Southern Ocean surface between Marine Isotope Stage 6 and 5d: Shape and timing of climate changes. Palaeogeogr. Palaeoclimatol. Palaeoecol. 187, 151-177. 
Bigler, M., Röthlisberger, R., Lambert, F., Stocker, T.F., Wagenbach, D., 2006. Aerosol deposited in East Antarctica over the last glacial cycle: detailed apportionment of continental and sea salt contributions. J. Geophys. Res. 111. doi:10.1029/2005JD006469.

Bintanja, R., van de Wal, R.S.W., Oerlemans, J., 2005. Modelled atmospheric temperatures and global sea levels over the past million years. Nature 437, 125-128.

Blunier, T., Schwander, J., Stauffer, B., Stocker, T., Dällenbach, A., Indermühle, A., Tschumi, J., Chappellaz, J., Raynaud, D., Barnola, J.-M., 1997. Timing of the Antarctic Cold Reversal and the atmospheric $\mathrm{CO}_{2}$ increase with respect to the Younger Dryas event. Geophys. Res. Lett. 24, 2683-2686.

Bowen, H.J.M., 1979. Environmental Chemistry of the Elements. Academic Press, London.

Brook, E.J., White, J.W.C., Schilla, A.S.M., M.L.B., Barnett, B., Severinghaus, J.P., Taylor, K.C., Alley, R.B., Steig, E.J., 2005. Timing of millenial-scale climate change at Siple Dome, West Antarctica, during the last glacial period. Quat. Sci. Rev. 24, 1333-1343.

Butzin, M., Prange, M., Lohmann, G., 2005. Radiocarbon simulations for the glacial ocean: the effects of wind stress, Southern Ocean sea ice and Heinrich events. Earth Planet. Sci. Lett. 235, 45-61.

de Angelis, M., Steffensen, J.P., Legrand, M., Clausen, H., Hammer, C., 1997. Primary aerosol (sea salt and soil dust) deposited in Greenland ice during the last climatic cycle: comparison with east Antarctic records. J. Geophys. Res. 102, 26681-26698.

Delmonte, B., Petit, J.R., Maggi, V., 2002. Glacial to Holocene implications of the new 27000-year dust record from the EPICA Dome C (East Antarctica) ice core. Clim. Dyn. 18, 647-660.

Delmonte, B., Basile-Doelsch, I., Petit, J.R., Maggi, V., RevelRolland, M., Michard, A., E.J., Grousset, F., 2004a. Comparing the EPICA and Vostok dust records during the last 220,000 years: stratigraphical correlation and provenance in glacial periods. Earth-Sci. Rev. 66, 63-87.

Delmonte, B., Petit, J.R., Andersen, K.K., Basile-Doelsch, I., Maggi, V., Lipenkov, V., 2004b. Dust size evidence for opposite regional atmospheric circulation changes over East Antarctica during the last climatic transition. Clim. Dyn. 23, 427-438.

Delmonte, B., Petit, J.R., Basile-Doelsch, I., Jagoutz, E., Maggi, V., 2007. Late Quaternary Interglacials in East Antarctica from ice core dust records. In: Sirocko, F., Claussen, M., Sanchez-Goni, M.F., Litt, T. (Eds.), The Clim. Past interglacials. Elsevier, Amsterdam, pp. $53-73$.

Diekmann, B., Kuhn, G., Rachold, V., Abelmann, A., Brathauer, U., Fütterer, D.K., Gersonde, R., Grobe, H., 2000. Terrigenous sediment supply in the Scotia Sea (Southern Ocean): response to late Quaternary ice dynamics in Patagonia and on the Antarctic Peninsula. Palaeogeogr. Palaeoclimatol. Palaeoecol. 162, 357-387.

EPICA community members, 2004. Eight glacial cycles from an Antarctic ice core. Nature 429, 623-628.

EPICA community members, 2006. One-to-one coupling of glacial climate variability in Greenland and Antarctica. Nature 444, 195-198.

Fischer, H., Siggaard-Andersen, M.-L., Ruth, U., Röthlisberger, R., Wolff, E., 2007. Glacial/interglacial changes in mineral dust and sea salt records in polar ice cores: sources, transport, deposition. Rev. Geophys. 45. doi:10.1029/2005RG000192.

Gersonde, R., Crosta, X., Abelmann, A., Armand, L., 2005. Sea-surface temperature and sea ice distribution of the Southern Ocean at the EPILOG Last Glacial Maximum — a circum-Antarctic view based on siliceous microfossil records. Quat. Sci. Rev. 24, 869-896.

Göktas, F., Fischer, H., Oerter, H., Weller, R., Sommer, S., Miller, H., 2002. A glacio-chemical characterisation of the new EPICA deep drilling site on Amundsenisen, Dronning Maud Land, Antarctica. Ann. Glaciol. 35, 347-354.

Gong, S.L., Barrie, L.A., Lazare, M., 2002. Canadian Aerosol Module (CAM): a size segregated simulation of atmospheric aerosol processes for climate and air quality models 2 . Global sea-salt aerosol and its budgets. J. Geophys. Res. 107. doi:10.1029/2001JD002004.

Graf, W., Oerter, H., Reinwarth, O., Stichler, W., Wilhelms, F., Miller, H., Mulvaney, R., 2002. Stable isotope records from Dronning Maud Land, Antarctica. Ann. Glaciol. 35, 195-201.

Grousset, F.E., Biscaye, P.E., Revel, M., Petit, J.-R., Pye, K., Joussaume, S., Jouzel, J., 1992. Antarctic (Dome C) ice core dust at 18 k.y. B.P.: isotopic constraints on origins. Earth Planet. Sci. Lett. 111, 175-182.

Hansson, M.E., 1994. The Renland ice core. A Northern Hemisphere record of aerosol composition over 120000 years. Tellus 46, $390-418$.

Hara, K., Osada, K., Kido, M., Hayashi, M., Matsunaga, K., Iwasaka, Y., Yamanouchi, T., Hashida, G., Fukatsu, T., 2004. Chemistry of sea-salt particles and inorganic halogen species in Antarctic regions: compositional differences between coastal and inland stations. J. Geophys. Res. 109. doi:10.1029/2004JD004713.

Huybrechts, P., Rybak, O., Pattyn, F., Ruth, U., Steinhage, D., 2007. Ice thinning, upstream advection, and non-climatic biases for the upper $89 \%$ of the EDML ice core from a nested model of the Antarctic ice sheet. Clim. Past Disc. 3, 693-727.

Jouzel, J., Masson-Delmotte, V., Cattani, O., Dreyfus, G., Falourd, S., Hoffmann, G., Minster, B., Nouet, J., Barnola, J.-M., Chappellaz, J., Fischer, H., Gallet, J.C., Johnsen, S., Leuenberger, M., Loulergue, L., Luethi, D., Oerter, H., Parrenin, F., Raisbeck, G., Raynaud, D., Schwander, J., Spahni, R., Souchez, R., Selmo, E., Schilt, A., Steffensen, J.P., Stenni, B., Stauffer, B., Stocker, T.F., Tison, J.-L., Werner, M., Wolff, E.W., in press. Orbital and millennial Antarctic climate variability over the last 800000 years. Science.

Kalnay, E., Kanamitsu, M., Kistler, R., Collins, W., Deaven, D., Gandin, L., Iredell, M., Saha, S., White, G., Woollen, J., Zhu, Y., Chelliah, M., Ebisuzaki, W., Higgins, W., Janowiak, J., Mo, K.C., Ropelewski, C., Wang, J., Leetmaa, A., Reynolds, R., Jenne, R., Joseph, D., 1996. The NCEP/NCAR 40-year reanalysis project. Bull. Am. Meteorol. Soc. 77, 437-471.

Knorr, G., Lohmann, G., 2003. Southern Ocean origin for the resumption of Atlantic thermohaline circulation during deglaciation. Nature 424, 532-536.

Köhler, P., Fischer, H., Munhoven, G., Zeebe, R.E., 2005. Quantitative interpretation of atmospheric carbon records over the last glacial termination. Glob. Biogeochem. Cycles 19. doi:10.1029/ 2004GB002345.

Krinner, G., Genthon, C., 1998. GCM simulation of the Last Glacial Maximum surface climate of Greenland and Antarctica. Clim. Dyn. 14, 741-758.

Lunt, D.J., Valdes, P.J., 2001. Dust transport to Dome C, Antarctica, at the Last Glacial Maximum and present day. Geophys. Res. Lett. 28, 295-298.

Mahowald, N., Kohfeld, K., Hansson, M., Balkanski, Y., Harrison, S.P., Prentice, I.C., Schulz, M., Rodhe, H., 1999. Dust sources and deposition during the last glacial maximum and current climate: a comparison of model results with paleodata from ice cores and marine sediments. J. Geophys. Res. 104, 15895-15916.

Mahowald, N.M., Muhs, D.R., Levis, S., Rasch, P.J., Yoshioka, M., Zender, C.S., Luo, C., 2006. Change in atmospheric mineral aerosols in response to climate: last glacial period, preindustrial, modern, and doubled carbon dioxide climates. J. Geophys. Res. 111. doi:10.1029/2005JD006653. 
Markgraf, V., Dodson, J.R., Kershaw, A.P., McGlone, M.S., Nicholls, N., 1992. Evolution of late Pleistocene and Holocene climates in the circum-South Pacific land areas. Clim. Dyn. 6, 193-211.

Martin, J., 1990. Glacial-interglacial $\mathrm{CO}_{2}$ change: the iron hypothesis. Paleoceanography $5,1-13$.

Mayewski, P.A., Twickler, M.S., Whitlow, S.I., Meeker, L.D., Yang, Q., Thomas, J., Kreutz, K., Grootes, P.M., Morse, D.L., Steig, E.J., Waddington, E.D., Saltzman, E.S., Whung, P.-Y., Taylor, K.C., 1996. Climate change during the last deglaciation in Antarctica. Science 272, 1636-1638.

Moreno, P.I., Lowell, T.V., Jacobson Jr., G.L., Denton, G.H., 1999. Abrupt vegetation and climate changes during the last glacial maximum and last termination in the Chilean Lake District. A case study from Canal de la Puntilla ( $\left.41^{\circ} \mathrm{S}\right)$. Geogr. Ann. 81A, 285-311.

Morgan, V., Delmotte, M., van Ommen, T., Jouzel, J., Chappellaz, J., Woon, S., Masson-Delmotte, V., Raynaud, D., 2002. Relative timing of deglacial climate events in Antarctica and Greenland. Science 297, 1862-1864.

Oerter, H., Wilhelms, F., Jung-Rothenhäusler, F., Göktas, F., Miller, H., Graf, W., Sommer, S., 2000. Accumulation rates in Dronning Maud Land, Antarctica, as revealed by dielectric-profiling measurements of shallow firn cores. Ann. Glaciol. 30, 27-34.

Otto-Bliesner, B.L., Brady, E.C., Clauzet, G., Tomas, R., Levis, S., Z.K., 2006. Last Glacial Maximum and Holocene climate in CCSM3. J. Clim. 19, 2526-2544.

Parrenin, F., Barnola, J.-M., Beer, J., Blunier, T., Castellano, E., Chappellaz, J., Dreyfus, G., Fischer, H., Fujita, S., Jouzel, J., Kawamura, K., Lemieux-Dudon, B., Loulergue, L., MassonDelmotte, V., Narcisi, B., Petit, J.-R., Raisbeck, G., Raynaud, D., Ruth, U., Schwander, J., Severi, M., Spahni, R., Steffensen, J.P., Svensson, A., Udisti, R., Waelbroeck, C., Wolff, E., 2007. The EDC3 agescale for the EPICA Dome C ice core. Clim. Past Disc. 3, 575-606.

Petit, J.R., Mounier, L., Jouzel, J., Korotkevich, Y.S., Kotlyakov, V., Lorius, C., 1990. Paleoclimatological and chronological implications of the Vostok core dust record. Nature 343, 429-436.

Petit, J.R., Jouzel, J., Raynaud, D., Barkov, N.I., Barnola, J.-M., Basile, I., Bender, M., Chappellaz, J., Davis, M., Delaygue, G., Delmotte, M., Kotlyakov, V.M., Legrand, M., Lipenkov, V.Y., Lorius, C., Pepin, L., Ritz, C., Saltzman, E., Stievenard, M., 1999. Climate and atmospheric history of the past 420,000 years from the Vostok ice core, Antarctica. Nature 399, 429-436.

Rankin, A.M., Auld, V., Wolff, E.W., 2000. Frost flowers as a source of fractionated sea salt aerosol in the polar regions. Geophys. Res. Lett. 27, 3469-3472.

Reader, M.C., McFarlane, N., 2003. Sea-salt aerosol distribution during the Last Glacial Maximum and its implications for mineral dust. J. Geophys. Res. 108. doi:10.1029/2002JD002063.

Reijmer, C.H., van den Broeke, M.R., 2001. Moisture sources of precipitation in Western Dronning Maud Land, Antarctica. Antarct. Sci. 13, 210-220.

Reijmer, C.H., van den Broeke, M.R., Scheele, M.P., 2002. Air parcel trajectories to five deep drilling locations on Antarctica, based on the ERA-15 data set. J. Clim. 15, 1957-1968.

Revel-Rolland, M., De Dekker, P., Delmonte, B., Hesse, P.P., Magee, J.W., Basile-Doelsch, I., Grousset, F., Bosch, D., 2006. Eastern Australia: a possible source of dust in East Antarctica interglacial ice. Earth Planet. Sci. Lett. 249, 1-13.

Röthlisberger, R., Bigler, M., Hutterli, M., Sommer, S., Stauffer, B., Junghans, H.G., Wagenbach, D., 2000. Technique for continuous high-resolution analysis of trace substances in firn and ice cores. Environ. Sci. Technol. 34, 338-342.
Röthlisberger, R., Mulvaney, R., Wolff, E.W., Hutterli, M., Bigler, M., Sommer, S., Jouzel, J., 2002. Dust and sea-salt variability in central East Antarctica (Dome C) over the last 45 kyrs and its implications for southern high-latitude climate. Geophys. Res. Lett. 29. doi:10.1029/2002GL015186.

Ruth, U., Barnola, J.-M., Beer, J., Bigler, M., Blunier, T., Castellano, E., Fischer, H., Fundel, F., Huybrechts, P., Kaufmann, P., Kipfstuhl, S., Lambrecht, A., Morganti, A., Oerter, H., Parrenin, F., Rybak, O., Severi, M., Udisti, R., Wilhelms, F., Wolff, E., 2007. "EDML1": A chronology for the EDML ice core, Antarctica, over the last 150 000 year. Clim. Past Disc. 3, 549-574.

Rybak, O., Huybrechts, P., Steinhage, D., Pattyn, F., 2005. Dating and accumulation rate reconstruction along the Dome Fuji - Kohnen radio-echo-sounding profile. Geophys. Res. Abstr. 7, 05421.

Schaefer, J.M., Denton, G.H., Barrell, D.J.A., Ivy-Ochs, S., Kubik, P.W., Andersen, B.G., Phillips, F.M., Lowell, T.V., Schlüchter, C., 2006. Near synchronous interhemispheric termination of the Last Glacial Maximum in mid-latitudes. Science 312, 1510-1513.

Severi, M., Castellano, E., Morganti, A., Udisti, R., Ruth, U., Fischer, H., Huybrechts, P., Wolff, E., Parrenin, F., Kaufmann, P., Lambert, F., Steffensen, J.P., 2007. Synchronisation of the EDML1 and EDC3 timescales for the last $52 \mathrm{kyr}$ by volcanic signature matching. Clim. Past Disc. 3, 409-433.

Shin, S.-I., Liu, Z., Otto-Bliesner, B., Brady, E.C., Kutzbach, J.E., Harrison, S.P., 2003. A simulation of the Last Glacial Maximum climate using the NCAR-CCSM. Clim. Dyn. 20, 127-151.

Sommer, S., Wagenbach, D., Mulvaney, R., Fischer, H., 2000. Glaciochemical study covering the past $2 \mathrm{kyr}$ on three ice cores from Dronning Maud Land, Antarctica 2. Seasonally resolved chemical records. J. Geophys. Res. 105, 29423-29433.

Steig, E.J., Brook, E.J., White, J.W.C., Sucher, C.M., Bender, M.L., Lehman, S.J., Morse, D.L., Waddington, E.D., Clow, G.D., 1998. Synchronous climate changes in Antarctica and the North Atlantic. Science 282, 92-95.

Steinhage, D., Nixdorf, U., Meyer, U., Miller, H., 2001. Subglacial topography and internal structure of central and western Dronning Maud Land, Antarctica, determined from airborne radio echo sounding. J. Appl. Geophys. 47, 183-189.

Stephens, B.B., Keeling, R.F., 2000. The influence of Antarctic sea ice on glacial-interglacial $\mathrm{CO}_{2}$ variations. Nature 404, 171-174.

Stocker, T., Johnsen, S., 2003. A minimum thermodynamic model of the bipolar seesaw. Paleoceanography 18. doi:10.1029/2003PA000920.

Sugden, D.E., Bentley, M.J., Fogwill, C.J., Hulton, N.R.J., McCulloch, R.D., Purves, R.S., 2005. Late-glacial glacier events in southernmost South America. Geogr. Ann. 87A, 273-288.

Toggweiler, J.R., 1999. Varition of atmospheric $\mathrm{CO}_{2}$ by ventilation of the ocean's deepest water. Paleoceanography 14, 571-588.

Toggweiler, J.R., Russell, J.L., Carson, S.R., 2006. Midlatitude westerlies, atmospheric $\mathrm{CO}_{2}$, and climate change during the ice ages. Paleoceanography 21. doi:10.1029/2005PA001154.

Udisti, R., Becagli, S., Benassai, S., de Angelis, M., Hansson, M.E., Jouzel, J., Schwander, J., Steffensen, J.P., Traversi, R., Wolff, E., 2004. Sensitivity of chemical species to climatic changes in the last $45 \mathrm{kyr}$ as revealed by high-resolution Dome C (East Antarctica) ice-core analysis. Ann. Glaciol. 39, 457-466.

Wagenbach, D., Ducroz, F., Mulvaney, R., Keck, L., Minikin, A., Legrand, M., Hall, J.S., Wolff, E.W., 1998. Sea-salt aerosol in coastal Antarctic regions. J. Geophys. Res. 103, 10961-10974.

Wainer, I., Clauzet, G., Ledru, M.-P., Brady, E.C., Otto-Bliesner, B., 2005. Last Glacial Maximum in South America: paleoclimate proxies and model results. Geophys. Res. Lett. 32. doi:10.1029/ 2004GL021244. 
Watanabe, O., Jouzel, J., Johnsen, S., Parrenin, F., Shoji, H., Yoshida, N., 2003. Homogeneous climate variability across East Antarctica over the past three glacial cycles. Nature 422, 509-512.

Werner, M., Tegen, I., Harrison, S.P., Kohfeld, K., Prentice, I.C., Balkanski, Y., Rodhe, H., Roelandt, C., 2002. Seasonal and interannual variability of the mineral dust cycle under present and glacial conditions. J. Geophys. Res. 107. doi:10.1029/2002JD002365.

Williams, G.P., Bryan, K., 2006. Ice age winds: an aquaplanet model. J. Clim. 19, 1706-1715.

Wolff, E.W., Rankin, A.M., Röthlisberger, R., 2003. An ice core indicator of Antarctic sea ice production? Geophys. Res. Lett. 30. doi:10.1029/2003GL018454.
Wolff, E.W., Fischer, H., Fundel, F., Ruth, U., Twarloh, B., Littot, G.C., Mulvaney, R., de Angelis, M., Boutron, C.F., Hansson, M., Jonsell, U., Hutterli, M., Bigler, M., Lambert, F., Kaufmann, P., Röthlisberger, R., Steffensen, J.P., Siggaard-Andersen, M.-L., Udisti, R., Becagli, S., Castellano, E., Severi, M., Wagenbach, D., Barbante, C., Gabrielli, P., Gaspari, V., 2006. Southern Ocean sea ice, DMS production and iron flux over the last eight glacial cycles. Nature 440, 491-496.

Yung, Y., Lee, T., Wang, C.-H., Shieh, Y.-T., 1996. Dust: a diagnostic of the hydrological cycle during the last glacial maximum. Science 271, 962-963. 